safety, and efficacy in the first year of clinical practice. Stroke 1998;29:18-22

19. Kase CS, Pessin MS, Zivin JA, et al. Intracranial hemorrhage after coronary thrombolysis with tissue plasminogen activator. Am J Med 1992;92:384-390.

20. Sloan MA, Sila CA, Mahaffey KW, et al. Clinical and radiographic factors associated with mortality following intracranial hemorrhage after thrombolysis for acute myocardial infarction. Stroke 1996;27:183. Abstract.

21. Gebel JM, Sila CA, Sloan MA, et al. Thrombolysis-related intracranial hemorrhage: a radiographic analysis of 244 cases from the GUSTO-1 trial with clinical correlation. Stroke 1998; 29:563-569.

22. Fisher CM, Adams RD. Observations on brain embolism with special reference to the mechanism of hemorrhagic infarction. J Neuropathol Exp Neurol 1951;10:92-93.

23. Lyden PD, Grotta JC, Levine SR, Marler JR, Frankel MR, Brott TG. Intravenous thrombolysis for acute stroke. Neurology 1997;49:14-29.

24. Ogata J, Yutani C, Imakita M, et al. Hemorrhagic infarct of the brain without a reopening of the occluded arteries in cardioembolic stroke. Stroke 1989;20:876-883.

25. Trouillas P, Nighoghossian N, Derex L, et al. Thrombolysis with intravenous rtPA in a series of 100 cases of acute carotid territory stroke: determination of etiological, topographic, and radiological outcome factors. Stroke 1998;29:2529-2540.

26. Larrue V, von Kummer R, del Zoppo G, Bluhmki E. Hemorrhagic transformation in acute ischemic stroke: potential contributing factors in the European Cooperative Acute Stroke Study. Stroke 1997;28:957-960.

27. Jaillard A, Cornu C, Durieux A, et al. Hemorrhagic transformation in acute ischemic stroke: the MAST-E study. Stroke 1999;30:1326-1332.

28. Weir CJ, Murray GD, Dyker AG, Lees KR. Is hyperglycemia an independent predictor of poor outcome after acute stroke? results of a long term follow up study. BMJ 1997;314:1303-1306.

29. Dietrich WD, Alonso O, Busto R. Moderate hyperglycemia worsens acute blood-brain barrier injury after forebrain ischemia in rats. Stroke 1993;24:111-116.

30. de Courten-Myers GM, Kleinholz M, Holm P, et al. Hemorrhagic infarct conversion in experimental stroke. Ann Emerg Med 1992;21:120-126.

31. Kawai N, Keep RF, Betz AL. Hyperglycemia and the vascular effects of cerebral ischemia. Stroke 1997;28:149-154.

32. Kalimo H, Rehncrona S, Soderfeldt B, Olsson Y, Siesjö BK. Brain lactic acidosis and ischemic cell damage, 2: histopathology. J Cereb Blood Flow Metab 1981;1:313-327.

\title{
Neuro/mages
}
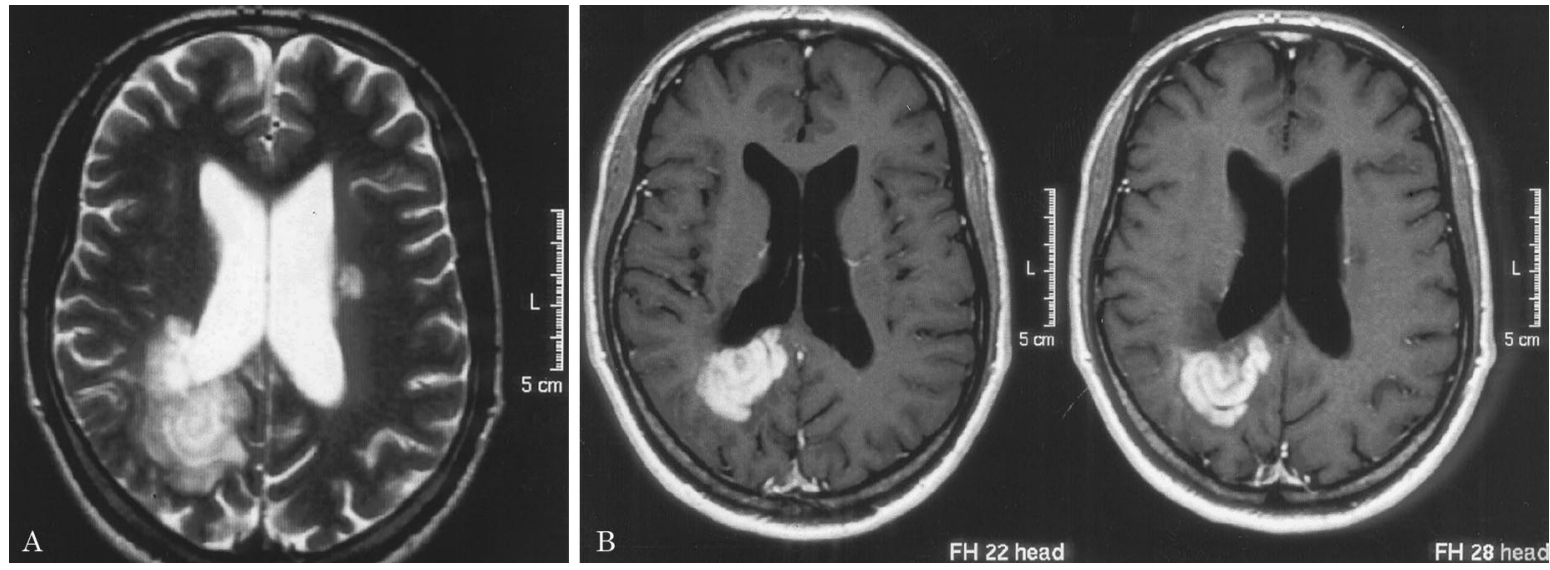

Figure. (A) Axial T2-weighted images show a large right occipitoparietal lesion with alternating concentric hyperintense and isointense rings. There is a small oval lesion on the left. (B) Axial T1-weighted images after administration of gadolinium-DTPA show marked and synchronous contrast enhancement of the hyperintense rings seen on the T2weighted images.

\section{Balo's concentric sclerosis demonstrated by contrast MRI}

O. Kastrup, MD, P. Stude, MD, V. Limmroth, $M D$ Essen, Germany

We report a 43-year-old man with Balo's concentric sclerosis. Clinically, he had recurring episodes of memory deficits and right-sided hemiparesis. MRI after application of gadolinium showed alternating bands of enhancement and rings of lack of enhancement corresponding with the rings of preserved myelin. ${ }^{1}$ There was synchronous enhancement of all lamellae (figure). CSF examination was abnormal, with mildly elevated cells $\left(29 / \mathrm{mm}^{3}\right)$ and protein $(56 \mathrm{mg} /$ $\mathrm{dL}$ ), but there was no intrathecal IgG synthesis or oligoclonal bands. The relationship of Balo's concentric sclerosis to MS continues to be unclear. ${ }^{2}$

1. Chen, CJ, Ro LS, Wang LJ, Wong YC. Balo's concentric sclerosis: MRI. Neuroradiology 1996;38:322-324.

2. Tersegno MM, Reich DR. Balo's concentric sclerosis: a rare form of multiple sclerosis manifested as a dominant cerebral mass without other white matter lesions on MR. AJR Am J Roentgenol 1993;160:901. Letter. 


\title{
Neurology
}

\author{
Balo's concentric sclerosis demonstrated by contrast MRI \\ O. Kastrup, P. Stude and V. Limmroth \\ Neurology 2001;57;1610 \\ DOI 10.1212/WNL.57.9.1610
}

This information is current as of November 13, 2001

\section{Updated Information \& Services}

\section{References}

Subspecialty Collections

Permissions \& Licensing

Reprints

\section{including high resolution figures, can be found at:} http://n.neurology.org/content/57/9/1610.full

This article cites 2 articles, 0 of which you can access for free at: http://n.neurology.org/content/57/9/1610.full\#ref-list-1

This article, along with others on similar topics, appears in the following collection(s):

\section{All Demyelinating disease (CNS)}

http://n.neurology.org/cgi/collection/all_demyelinating_disease_cns MRI

http://n.neurology.org/cgi/collection/mri

Multiple sclerosis

http://n.neurology.org/cgi/collection/multiple_sclerosis

Information about reproducing this article in parts (figures,tables) or in its entirety can be found online at:

http://www.neurology.org/about/about_the_journal\#permissions

Information about ordering reprints can be found online: http://n.neurology.org/subscribers/advertise

Neurology ${ }^{\circledR}$ is the official journal of the American Academy of Neurology. Published continuously since 1951, it is now a weekly with 48 issues per year. Copyright . All rights reserved. Print ISSN: 0028-3878.

Online ISSN: 1526-632X.

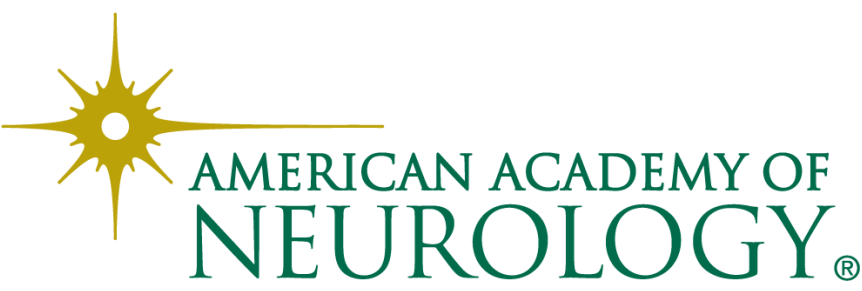

